\title{
Risky drinkers and their physicians
}

\author{
Hana Sovinova ${ }^{1 *}$, Ladislav Csemy ${ }^{2}$ \\ From INEBRIA 12th Congress, \\ Atlanda, GA, USA. 24-25 September 2015
}

\section{Background}

The study is focused on prevalence of risky and harmful drinking in Czech adults and on opinions of Czech GPs about the impact of alcohol on health of their patients. Self-assessment of doctors' effectiveness in reduction of patients' alcohol consumption was also addressed.

\section{Material and methods}

The results presented are based on the National Survey on Tobacco Smoking and Alcohol Consumption $(\mathrm{N}=$ $1,802)[1,2]$ and on a survey of 294 Czech GPs carried out within the ODHIN project $[3,4]$.

\section{Results}

Risky or harmful alcohol consumption was found in one in five Czech adults. 34\% of respondents reported their doctor asked them about alcohol consumption and 8.6\% received advice to reduce or stop drinking. This advice was more common for respondents over 45 years of age. In contrast with this only 22 respondents (1.2\%) felt they would need professional help [1,2]. About one third of the sample of Czech GPs considered None or very low drinking as very important for good health. Greater importance doctors attributed to other risk behaviors. The study identified lack of time, lack of professional training and lack of funding for preventive activities as barriers to broader implementation of alcohol consumption screening and brief intervention (SBI). Only $8.5 \%$ of GPs reported they were very effective in influencing drinking habits among their patients. $32 \%$ subjectively believe their efficiency in this area would be increased with adequate specialized training [3].

\section{Conclusions}

Only eight to nine percent of PHC patients receive recommendation to reduce drinking. GPs feel insecure regarding SBI to reduce alcohol consumption in patients, which could be changed if adequate education is provided. To overcome major barriers of wider implementation of SBI in PHC joint efforts and common interest of GPs, health insurance agencies and the Ministry of Health are needed.

\section{Acknowledgements}

The research has received funding from the European Union's Seventh Framework Programme for research, technological development and demonstration under grant agreement no 259268 - Optimizing delivery of health care intervention (ODHIN).

Research has been financially supported by a grant from the Czech Ministry of Education no. ODHIN-7E11001 and received institutional support of the Czech Ministry of Health.

\section{Authors' details}

${ }^{1}$ Monitoring and research center for tobacco and alcohol, National Institute of Public Health, Prague, Czech Republic. ${ }^{2}$ National Institute of Mental Health, Klecany, Czech Republic.

\section{Published: 24 September 2015}

\section{References}

1. Sovinová H, Csémy L: Užívání tabáku a alkoholu v České republice 2012. Státní zdravotní ústav, Praha; 2013, http://www.szu.cz.

2. Sovinová $H, C$ cémy $L$, Kernová V: Užívání tabáku a alkoholu v České republice: Zpráva o situaci za období posledních deseti let. Státní zdravotní ústav, Praha; 2014.

3. Csémy L, Sovinová H: Alkohol v primární zdravotní péči: zkušenosti, názory a postoje českých praktických lékařů. Prakt. lék 2015, 95:77-82.

4. Anderson P, Wojnar M, Jakubczyk A, Gual A, Reynolds J, Segura L, Kolsek M: Managing alcohol problems in general practice in Europe: results from the European ODHIN survey of general practitioners. Alcohol and Alcoholism 2014, 49:531-539.

doi:10.1186/1940-0640-10-S2-P11

Cite this article as: Sovinova and Csemy: Risky drinkers and their physicians. Addiction Science \& Clinical Practice 2015 10(Suppl 2):P11.

\footnotetext{
* Correspondence: hana.sovinova@szu.cz

${ }^{1}$ Monitoring and research center for tobacco and alcohol, National Institute of Public Health, Prague, Czech Republic

Full list of author information is available at the end of the article
} 